\title{
HUBUNGAN KOPING STRES DENGAN KEPATUHAN MINUM OBAT PADA PENDERITA TUBERKULOSIS PARU
}

\author{
${ }^{1}$ Friska Ernita Sitorus, ${ }^{2}$ Dewi Tiansa Barus \\ Institut Kesehatan DELI HUSADA Deli Tua \\ Jl.Besar No 77, Kec. Deli Tua, Kab.Deli Serdang Sumatera Utara 20355 \\ email : friskasitorus87@gmail.com
}

\begin{abstract}
Pulmonary Tuberculosis (TB) is an infectious disease that still has became theworld concern. In Indonesia, pulmonary tuberculosis is still major communityhealth problem eventhough the goverment have already develop Tuberculosis programsince decade ago. The purpose of this research is to describe factors contributing to pulmonary tuberculosis through general characteristic of the pulmonary Tubeculos is patients and their environmental especially housing condition. The aims of Reseach to know the relationship of coping stress with adherence to Medication in people with Tuberculosis in Delitua Sub district health centers Delitua Deli Serdang district the year 2017. The study is Observational, analytic approach of cross sectional. The subject of research was Pulmonary Tuberculosis sufferers in the region Delitua, County Health Center Deliserdang. The Data of obtained by the used of questionnaires and direct observations in the neighborhood Health Center. Sampling of the techniques, namely the minimum number of samples with 61 samples. The data using computer programs with the chi-square test with a significance level of $95 \%(a=0.05)$ value $p$ $=0.001$. The results of the data analysis Univariate statistics for trials with Koping stress indicate that the average sufferer of Tuberculosis are at categories de-stress kopingAdaktif $70.5 \%$, as for compliance with medication is at a category i.e. $82.0 \%$ Obedient, Chi-square test results Showed there is Relationship stress Compliance with the Koping medication (0.001). The conclusions of this Reasech showed that stress Koping have relationships with Medication Compliance.
\end{abstract}

Keywords: Tuberculosis, Coping Stress, Medication Compliance

\section{PENDAHULUAN}

Berdasarkan WHO Penderita TB Paru secara global adalah sebanyak 8,6 juta. Hingga saat ini keberhasilan pengobatan Tuberkulosis Paru masih berkisar $86 \%$. Indonesia merupakan negara kedua yang mempunyai penderita Tuberkulosis Paru yaitu $10 \%$ dari total penderita TB Paru di dunia (WHO,2015)

Pada tahun 2014 Provinsi Sumatera Utara juga mengalami peningkatan yang signifikan dalam penderita TB Paru yaitu sebanyak $24.052(76,35 \%)$ dengan prevalensi $174,71 / 100.000$ penduduk Sumatera Utara (Dinkes Prov SU, 2015).
Dari data yang didapatkan dari Dinkes Deli Serdang (2013) mengatakan bahwa penderita TB paru tahun 2012 adalah 2.616 (75,79\%) jiwa dan prevalensi sebesar 142/100.000 dari total penduduk Deli Serdang. Kemudian pada tahun 2014 Penderita TB.Paru di kabupaten Deli Serdang mengalami peningkatan yaitu 2.886 (Dinkes Deli Serdang, 2015).

$$
\text { Penyakit }
$$

tuberkulosis merupakan penyakit yang menjadi masalah kesehatan baik tingkat nasional maupun tingkat dunia. Mycobacterium tuberkulosis telah menginfeksi sepertiga penduduk dunia, penyakit TB Paru merupakan penyakit 
yang menjalani pengobatan secara rutin dengan jangka $6-8$ bulan (Laban, 2008).

Kesembuhan penderita TB Paru tergantung dari berbagai faktor, salah satunya adalah kepatuhan minum obat, untuk mempertahankan kepatuhan penderita TB paru dibututuhkan motivasi dari keluarga atau orang terdekat. Banyak penderita TB Paru yang gagal dalam pengobatan, sehingga penderita harus mengulang pengobatan dari awal(Fitriatun, 2006).

Mekanisme koping merupakan suatu perilaku pemecahan masalah yang tujuannya untuk mentralkan situasi dalam kehidupan. Mekanisme pemecahan masalah stres yang dapat dilakukan oleh penderita TB paru berupa koping adaptif (efektif) dan koping maladaptif (inefektif), Suliswati (2005). Mekanisme koping merupakan suatu usaha yang dilakukan seseorang dalam menghadapai masalahnya (Stuart GW, 2005). Keliat (2005) juga mengatakan dalam teorinya bahwa mekanisme koping adalah cara yang dilakukan seseorang dalam menghadapi masalahnya, menyesuaikan diri terhadap semua situasi yang bersifat mengancam sehingga penderita TB Paru tidak takut dalam menjalani pengobatan nya.

Penelitian strategi koping pasien dari beberapa penyakit berat yang dilakukan oleh Ernita (2010) dan Widiastuti (2003) menunjukan bahwa problem psikologis yang dihadapi penderita adalah stres, putus asa dan takut akan kematian, strategi koping yang digunakan individu adalah dengan cara menangis, Berbagai penelitian menunjukkan bahwa koping yang berbeda-beda pada pasien dari berbagai penyakit, untuk pasien TB paru memiliki mekanisme koping dengan menjalani pengobatan 6 bulan, sehingga penderita TB paru mengalami kejenuhan saat minum obat.

\section{METODE}

Jenis penelitian ini adalah Analitik Observasional dengan desain penelitian cross sectional yang bertujuan untuk menganalisis hubungan koping stres dengan kepatuhan minumobat pada penderita TB.Paru di wilayah kerja puskesmas Delitua. Pengukuran atau pengamatan dilakukan pada saat bersamaan pada data variabel independen dan dependen (sekali waktu).

Penelitian ini dilakukan di Wilayah Kerja Puskesmas Delitua. Populasi dalam penelitian ini adalah seluruh pasien TB.Paru di wilayah kerja puskesmas delitua, dengan menggunakan sampel minimum dengan nilai probabilitas 0,2 maka ditetapkan jumlah sampel adalah 61 responden dengan kriteria inklusi penderita TB yang sedang menjalani pengobatan dan kriteria ekslusi penderita TB+HIV.

Instrumen yang digunakan untuk pelaksanaan penelitian adalah dengan menggunakan kuisioner koping stres yang terdiri dari 20 pernyataan dengan hasil ukur koping adaptif dan koping maladaptif, selanjutnya kuisioner kepatuhan minum obat yang terdiri dari 2 pernyataan dengan hasil ukur patuh dan tidak patuh.

Data di analisis dengan menggunakan metode univariat yang bertujuan untuk mengetahui distribusi frekuensi karakteristik responden, variabel independen dan dependen, dan uji bivariat dengan menggunakan uji chi-square yang bertujuan untuk menganalisis hubungan koping stres dengan kepatuhan minum obat pada penderita TB paru di wilayah kerja puskesmas Delitua 
3. HASIL

\section{a. Karakteristik Responden}

Berdasarkan

karakteristik responden dapat dilihat bahwa mayoritas usia penderita TB.Paru adalah usia 29-39 tahun yaitu 35,9\%, berdasarkan pekerjaan mayoritas responden sebagai buruh yaitu 52,9\%, berdasarkan jenis kelamin mayoritas berponden adalah laki-laki yaitu sebanyak 63,9\%, dan berdasarkan pendidikan mayoritas penderita TB.Paru adalah berpendidikan SD yaitu sebanyak $37,7 \%$.

Tabel 1. Distribusi frekuensi karakteristik responden

\begin{tabular}{clcc}
\hline No & Karakteristik & f & \% \\
\hline \multirow{2}{*}{1} & Usia & & \\
& 29-39 Tahun & 14 & 22.8 \\
& 40-48 Tahun & 23 & 35.9 \\
& $\geq 49$ Tahun & 24 & 39.3 \\
\hline \multirow{2}{*}{2 Pekerjaan } & & \\
2 & Buruh & 32 & 52.5 \\
& Pedagang & 22 & 36 \\
& IRT & 7 & 11.5 \\
\hline \multirow{2}{*}{3 Jenis Kelamin } & & \\
& Laki-Laki & 39 & 63.9 \\
& Perempuan & 22 & 36.1 \\
\hline \multirow{4}{*}{ Pendidikan } & & \\
& SD & 23 & 37.7 \\
SMP & 13 & 21.3 \\
& SMA & 18 & 29.5 \\
& PT & 7 & 11.5 \\
\hline
\end{tabular}

\section{b. Koping Stres}

Koping stres responden dalam penelitian ini dibagi menjadi dua kategori, frekuensi distribusi koping stres dapat dilihat pada tabel berikut.

\begin{tabular}{|c|c|c|c|}
\hline $\begin{array}{l}\text { Tab } \\
\text { Res } \\
\text { stre }\end{array}$ & $\begin{array}{l}2 . \\
\text { onden }\end{array}$ & $\begin{array}{l}\text { usi } \\
\text { arkan }\end{array}$ & $\begin{array}{l}\text { ekuens } \\
\text { koping }\end{array}$ \\
\hline No & Koping Stres & $f$ & $\%$ \\
\hline 1 & Adaptif & 43 & 70,5 \\
\hline 2 & Maladaptif & 18 & 29,5 \\
\hline
\end{tabular}

\section{c. Kepatuhan Minum Obat}

Kepatuhan minum obat responden dalam penelitian ini dibagi menjadi dua kategori, frekuensi kepatuhan minum obat dapat dilihat dalam tabel berikut.

Tabel 3. Distribusi Frekuensi Responden berdasarkan Kepatuhan Minum Obat. $(\mathbf{n}=61)$

\begin{tabular}{llcc}
\hline No & Kepatuhan & $\mathrm{f}$ & $\%$ \\
\hline 1 & Patuh & 50 & 82 \\
2 & Tidak Patuh & 11 & 18 \\
\hline
\end{tabular}

\section{d. Hubungan Koping stres dengan kepatuhan Minum obat penderita Tuberkulosis Paru}

Berdasarkan hasil penelitian menunjukan bahwa 43 (70,4 \%) orang yang memiliki koping stres adaktif , 40 orang $(80,0 \%)$ patuh dan 3 orang $(27,2 \%)$ tidak patuh, sedangkan responden yang memiliki koping stres maladaktif sebanyak 18 orang $(29,5 \%)$, diantaranya 10 orang $(20,0 \%)$ patuh minum obat dan 8 orang $(72,7 \%)$ tidak patuh minum obat. Berdasarkan hasil uji statistik dengan menggunakan chisquare menunjukan bahwa pvalue $(=0,05)<a(=0,01)$. Maka dapat disimpulkan Bahwa Ha diterima yaitu ada hubungan Koping stres dengan kepatuhan minum obat di Puskesmas Delitua Tahun 2017.

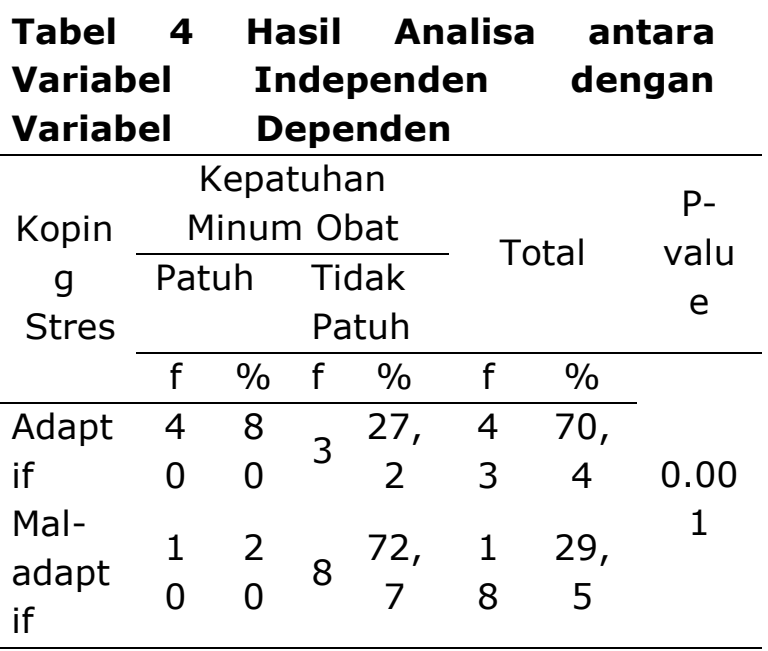




\section{PEMBAHASAN}

\section{a. Koping Stres}

Kemampuan menghadapi stres berbeda pada setiap individu tergantung kemampuan koping yang dimiliki. Koping merupakan respon yang dilakukan tubuh untuk mengurangi beban fisik, emosional, dan psikologis yang berhubungan dengan aktivitas atau kesibukan sehari-hari (Snyder, 1999)

Bagaimana orang berupaya mengatasi masalah atau menangani emosi yang umumnya negatif yang ditimbulkanya. Bahkan di antara mereka yang menilai suatu situasi sebagai penuh stres, efek stres dapat bervariasi tergantung pada bagaimana individu menghadapi situasi sebagai penuh stres, efek stres dapat bervariasi tergantung bagaimana individu menghadapi berbagai situasi yang terjadi (Gerald C.Davison, 2010). Dari hasil Distribusi Frekuensi Responden yang memiliki Koping stres adaktif sebanyak 43 orang $(70,5 \%)$, dan koping stres maladaktif sebanyak 18 orang $(22,5 \%)$. Dapat dilhat dari tabel frekuensi diatas bahwa responden yang memiliki respon koping adaptif lebih banyak dibandingkan koping stres maladaktif.

Koping yang efektif dan tepat akan memberikan kemampuan kepada pasien untuk menyesuaikan diri atau menghadapi stressor seperti; nyeri, hilangnya sebagian fungsi tubuh, mualmuntah, anoreksia, kelelahan, penurunan mobilitas, isolasi sosial, harga diri, ketidakpastian, takut akan kematian penyesuaian diri dengan lingkungan rumah sakit, dan sebagainya (Keliat, 1997).

Depresi dapat menimbulkan keinginan seseorang dalam menyelesaikan pekerjaan dan hasil yang diinginkan. Depresi dapat berkontribusi pada penurunan fungsi fisik dan emosional yang menyebabkan seseorang menjadi kehilangan motivasi untuk melakukan perawatan diri secara rutin (Lustman, 2000 dalam Wu, 2007).

\section{b.Kepatuhan Minum Obat}

Penderita yang patuh berobat adalah yang menyelesaikan pengobatan secara teratur dan lengkap tanpa terputus selama minimal 6 bulan sampai dengan 9 bulan (Depkes RI, 2010). Dari hasil distribusi frekuensi didapatkan bahwa responden yang patuh minum obat sebanyak 50 orang $(82,0 \%)$, sedangkan responden yang tidak patuh 11 orang $(18,0 \%)$.

Tampak bahwa dari tabel distribusi frekuensi responden sebanyak 61 orang dominan paling banyak patuh minum obat, walapun efek samping obat OAT sangat berdampak pada Tubuh mereka akan tetapi respon keinginan pasien untuk sembuh dari penyakit Tuberkulosis sangat besar.

Hasil penelitian Setyawan (2007) yang menyatakan bahwa variabel usia, tingkat pendidikan, pekerjaan, status pernikahan, keterlibatan dalam masalah hukum dan kepribadian disosial merupakan variabel yang berpotensi sebagai variabel perancu terhadap kepatuhan pasien.

\section{c. Hubungan Koping Stres Dengan Kepatuhan Minum Obat}

Penelitian strategi koping pasien dari beberapa penyakit berat yang dilakukan oleh Ernita (2010) dan Widiastuti (2003), menunjukan bahwa problem psikologis yang dihadapi penderita adalah stres, merasa bersalah, putus asa dan ketakutan akan kematian dalam hidup, strategi koping yang digunakan pasien adalah menangis, Berbagai penelitian menunjukkan bahwa koping yang berbeda-beda pada pasien dari berbagai penyakit, untuk pasien TB paru memiliki mekanisme koping 
dengan menjalani pengobatan 6 bulan, sehingga penderita TB paru mengalami kejenuhan saat minum obat.

Berdasarkan penelitian dukungan sosial pada penderita $\mathrm{Tb}$ paru menunjukkan sebagian besar pasien memperoleh dukungan sosial yang sedang mempunyai kualitas hidup yang sedang, terlihat dari data yang diperoleh bahwa semakin sedikitnya dukungan sosial yang dirasakan oleh pasien maka semakin berpengaruh terhadap penurunan kualitas hidupnya. Sedangkan pada coping stres pasien, sebagian besar pasien mampu mengatasi stresnya dalam kategori sedang. Hal ini menyebabkan adanya perubahan pada kualitas hidup namun tidak banyak pengaruhnya. Hasil penelitian menunjukkan jumlah pasien dengan coping stres sedang yang mempunyai kualitas hidup sedang dan mempunyai kualitas hidup baik jumlahnya hampir sama. (Issa, 2009).

Dari hasil distribusi ferekuensi menunjukan bahwa $43(70,4 \%)$ orang yang memiliki koping stres adaktif , 40 orang $(80,0 \%)$ patuh dan 3 orang $(27,2 \%)$ tidak patuh, sedangkan responden yang memiliki koping stres maladaktif sebanyak 18 orang $(29,5 \%)$, diantaranya 10 orang $(20,0 \%)$ patuh minum obat dan 8 orang $(72,7 \%)$ tidak patuh minum obat.

Berdasarkan hasil uji statistik dengan menggunakan chi-square menunjukan bahwa pValue $(=0,05)<a(=0,01)$. Maka dapat disimpulkan Bahwa $\mathrm{Ha}$ diterima yaitu ada hubungan Koping stres dengan kepatuhan minum obat di Puskesmas Delitua Tahun 2017

\section{KESIMPULAN}

Berdasarkan hasil distribusi frekuensi menunjukkan bahwa $43(70,4$ $\%)$ orang yang memiliki koping stres adaktif , 40 orang $(80,0 \%)$ patuh dan 3 orang $(27,2 \%)$ tidak patuh, sedangkan responden yang memiliki koping stres maladaktif sebanyak 18 orang $(29,5 \%)$, diantaranya 10 orang $(20,0 \%)$ patuh minum obat dan 8 orang $(72,7 \%)$ tidak patuh minum obat.

Berdasarkan hasil uji statistik dengan menggunakan chi-square menunjukan bahwa pValue $(=0,05)<a$ $(=0,01)$. Maka dapat disimpulkan Bahwa Ha diterima yaitu ada hubungan Koping stres dengan kepatuhan minum obat di Wilayah Kerja Puskesmas Delitua Tahun 2017.

\section{DAFTAR PUSTAKA}

Depkes RI. 2010. Pedoman Nasional Penanggulangan Tuberkulosis. Jakarta: Depkes.

Dinkes Prov SU. Profil Kesehatan Provinsi Sumatera Utara Tahun 2015. Medan; Dinas Kesehatan Provinsi Sumatera Utara. 2015.

Dinkes Kab.Deli Serdang. Profil Dinas Kesehatan Kab.Deli Serdang. 2015

Ernita Novalia. (2010). Koping Pasien Gagal Ginjal Kronis Yang Menjalani Hemodialisa di Rumah Sakit Umum Pusat H.Adam Malik Medan. http://repository.usu.ac.id/bitstrea m/123456789/24973/6/Abstract.pd f. Diunduh Tanggal 15 November 2017.

Fitriatun Rosidah. 2006. Beberapa faktor Yang berhubungan dengan keberhasilan pengobatan TB Paru Di BP4 Tegal Tahun 2006. Semarang. Universitas Muhhammdiyah Semarang

Gerald C.Davison, John M.Neale, Ann M.Kring. 2010. Psikologi Abnormal (diterjemahkan oleh Noermalasari Fajar), edisi ke-9, Jakarta: Raja Garfindo Persada

Issa $B A$, Yusuf AD, Kurangga SI. Depression comorbidity among patients with tuberculosis in a 
university teaching hospital outpatient clinic in Nigeria. Mental Health in Family Medicine; 2009. Vol 6 (3):133-8.

Keliat, B.A., 1997, Gangguan Koping, Citra Tubuh, dan Seksual pada Klien Kanker. Penerbit Buku Kedokteran EGC, Jakarta,

Keliat Budi A, 2005, Proses Keperawatan Jiwa, Edisi 2, Jakarta : EGC

Laban, Yoannes. 2008. TBC Penyakit Dan Cara Pencegahannya. Yogyakarta: Kanisius

Setyawan AB., 2007, Hubungan Antara Fungsi Keluarga Dengan Kepatuhan Berobat Pasien Program Terapi Rumatan Metadon RSU Dr. Soetomo Surabaya, Bagian Psikiatri Fakultas Kedokteran Universitas Wijaya Kusuma, Surabaya.

Stuart GW \& Laraia, 2005, Principles and practice of psychiatric nursing, Elsevier Mosby, Alih Bahasa Budi Santosa, Philadelphia

Snyder, C, R. 1999. Coping; The Psychology of what work World Health Organization (WHO). Global Tuberculosis Report 2015. Switzerland. 2015.

Widyastuti. (2003). Mekanisme Koping Penderita Diabetes Militus. Artikel : STIKES Maharani Malang.

Wu, S.F.V., Courtney, M., Edward, H., McDowell, J., Shortridge-Baggett, L.M., Chang, P.J., 2006. Selfefficacy, outcome expectation and self care behavior in $p$ with type diabetes in taiwan. 